\title{
Investing in Retrenchment: Avoiding the Hidden Costs
}

\section{Cynthia Hardy}

- In 1976, the managers of Northville Area Health Authority (AHA) put forward a plan to close Maine Road Maternity Hospital. The AHA is part of the British National Health Service (NHS), responsible for the administration of all hospitals in Northville, a city in the north of England. Senior management is responsible for making recommendations to the AHA, whose members include medical representatives, interested lay people, and members of the local council. The AHA has decision-making power and can choose to accept or reject managerial recommendations. ${ }^{1}$

Maine Road had been a candidate for closure since the 1960s, simply because it was an old hospital. A fall in the birth rate and a move of people out of the inner city area in the 1970s made it clear that Northville had an overprovision of maternity beds and the proposal to close Maine Road was made.

A number of groups immediately expressed concern. Staff at the hospital set up an action committee to stop the closure. They appeared on TV and radio, received sympathetic press coverage, lobbied Members of Parliament (MPs), and presented the AHA with a petition opposing the closure that contained more than 10,000 signatures. A consultant obstetrician at the hospital criticized the closure on TV and radio, in the local newspapers, and at public meetings. A national TV program on the issue was aired. The two Community Health Councils ( $\mathrm{CHCs}$ ), representing patient interests, and the National Union of Public Employees also opposed the proposal.

Bowing to this pressure, the AHA voted against management's recommendation, retaining the hospital and closing maternity wards in other hospitals. Had the AHA not taken this action, the union was ready and willing to make plans for the occupation of the hospital in an attempt to force a change of heart, even though they agreed in principle with the fact that the city had too many maternity beds.

The handling of this and other cuts resulted in increasing criticism of management by unions, $\mathrm{CHCs}$, employees, politicians, and the public. The uproar culminated in a massive protest in May 1977. A delegation was sent to the minister of health, who, as a result, set up a committee of inquiry into the health area. The committee, in turn, was very critical of management's actions.

- In 1975, Imperial Chemical Industries (ICI) announced that Mountside works could look forward to a life expectancy of only five to ten years. The following year, it announced that the closure was to start immediately. Mountside was a chemical factory in the north of England, employing over 1,000 individuals. Competitive pressures from European 
producers with large integrated sites and low overheads had prompted the division to reduce the number of manufacturing sites. Mountside was one of those scheduled for closure. The bulk of the rundown was carried out between 1976 and 1978, although the works did not close completely until 1980 . The rundown was a long and tightly scheduled process since some products were being transferred to other plants, and facilities had to be built up.

Local stewards raised the issue with national officials, who saw no reason not to accept the closure. Discussions about how the process was to be carried out and how employees were to be protected were carried out successfully at the local level, without resorting to grievance procedure. There was no industrial action or loss of production; productivity remained stable over the first three years of the rundown; absenteeism fell; the rundown schedule was adhered to; local press coverage was low-key and generally supportive of the company, while national exposure was nonexistent; and, perhaps most importantly, of all the stewards, union officials, and employees interviewed, none criticized the company's actions.

What differentiates these two organizations is clear-ICI was able to implement its plans while Northville was not. However, Northville managers lost more than the opportunity to save $£ 500,000$ a year by closing a hospital: they also incurred many of the "hidden" costs associated with retrenchment, while ICI incurred virtually none. Northville managers provoked union action, alienated employees, damaged their own credibility, evoked government intervention, and generated public criticism. They also jeopardized the larger retrenchment strategy designed to reduce their annual deficit of $£ 1$ million and accommodate government spending cuts.

\section{The Hidden Costs of Retrenchment}

All too often, costs such as those incurred at Northville are neglectedmany companies view retrenchment as an isolated and unpleasant incident, best carried out and forgotten as quickly as possible. This attitude ignores the fact that retrenchment is not purely about disbanding operations: it is often part of a strategy designed to sustain the larger organization. When the global picture is taken into consideration, it becomes clear that the hidden costs are significant and can jeopardize the future survival of the organization. There are a number of factors which give rise to these hidden costs.

Union resistance, regardless of the form it takes, causes major problems for management. A strike weakens the larger organization. Occupations, in which employees take over the factory or hospital in question to prevent the sale of assets or transfer of production, are expensive. Even in North America where such overt resistance is less common, unions can withdraw cooperation, make contract negotiations difficult, initiate grievances, and prevent the smooth transfer of production, all of which represent additional costs to managers wishing to make effective cost savings.

Employers often dismiss the impact retrenchment has on continuing employees, seeing the problem purely in terms of those who leave. Yet 
the survivors are crucial to the future success of the organization and if they are alienated, productivity will fall; commitment will be reduced and may result in people leaving the organization as soon as the opportunity arises; creativity and innovation will be difficult to foster; and employees will be reluctant to make the concessions and sacrifices integral to future competitiveness. Companies which change policies of job security are particularly vulnerable if employees feel management is reneging on past promises and compromising managerial credibility over the handling of cutbacks. This makes it difficult to foster a creative and effective team spirit at a time when it is most needed.

Unfavorable publicity is another cost. If detailed reports of cutbacks are published, customers may start to worry that the firm is going out of business. Potential new recruits will look elsewhere for jobs if they feel that the organization has a poor record. Union officials and employees in other plants may become interested-and anxious. Community officials will start to question decisions and actions.

Organizations linked to the public sector will want to avoid political intervention. Government officials may have the ability to revoke cutback decisions if they feel that they have been handled in a way that is politically embarrassing. Even where intervention is less direct, the clumsy handling of retrenchment can lead to a series of difficult questions for senior managers. Private organizations are not exempt from political interference: contracts are awarded, subsidies granted, and payments made from government sources - and all of these can be jeopardized by retrenchment actions that meet with government disapproval.

Plant closures, cutbacks, and the rationalization of operations have been and will continue to be one of the major challenges facing contemporary managers. Increasing economic uncertainty and tough foreign competition are making such decisions imperative. Managing them in a way that incurs the costs described above will be expensive-particularly in the long term, as the struggle to restore viability unfolds. For these reasons, retrenchment must be considered to be an investment in the future, since contraction is the price paid for future success. Retrenchment deserves the same creative analysis as any other investment decision; otherwise, downgrading-rather than downsizing - will be the result.

Despite the emphasis on the global view in this and other articles, ${ }^{2}$ managers continue to adopt a short-term perspective. This is particularly true of the U.S., where "the right to close a business down has long been regarded as a management prerogative." ${ }^{3}$ As a result, legislation is minimal, owing to concerted resistance; and, even where it does exist, it is often not complied with. ${ }^{4}$ Despite some claims that a consensus is developing around the need for severance, notice, extended health care, and outplacement, there is little evidence to support the view that such practices constitute a widespread phenomenon. In fact in 1985, a bill requiring 
90-days notice of plant closure was defeated in the House of Representatives, while only three states have advance warning legislation in place. ${ }^{5}$ Moreover, there continue to be examples of plants closed with no notice or outplacement aid, particularly when companies relocate plants in areas of nonunionized labor. ${ }^{6}$ It would seem then that many American employers require convincing of, and information about, the need to view retrenchment as an investment.

The U.S. can look to both Canada and Europe on these matters. Both are far in advance of the U.S. in terms of legislation and practice and, as has been pointed out, initiatives in these countries often precede action in the U.S. ${ }^{7}$ This article, by examining ten Canadian and British organizations (including Northville and ICI), identifies the tasks associated with the successful management of retrenchment. These organizations were part of a study carried out since 1978 in both public and private sectors. ICI and Northville represent the extremes; the remaining organizations incurred some costs, and avoided others, during their experience with retrenchment (see Table 1).

\section{Avoiding the Costs}

Many of the costs associated with downsizing can be avoided with the implementation of a retrenchment program that takes into account the needs of both the departing and continuing employees, as well as the unions and other interest groups which are involved. This would allay many of the fears associated with cutbacks and would help employees to view retrenchment as a challenge rather than a threat, enabling them to respond positively to the increased demands and changes required of them. Individuals must be convinced that the cutbacks are a step towards increased profitability and efficiency, that there are opportunities associated with a more streamlined operation, that their increased effort will be rewarded, and that their concerns will not be ignored. The remainder of this article addresses the tasks required of management in this respect.

\section{The Task: Managing Awareness}

"We were able to say: let's do it, we have the time to do it; let's not wait until the crisis is so great all we can do is swing the axe. We have the time to do it in a more socially responsible way; in a way that minimizes the hurt on people, so let's do it before it is forced upon us in a more unpleasant way."-a human resource executive

Once the costs of retrenchment have been ascertained and the larger picture established, the situation of the individual organization can be assessed in terms of whether there is a need to adopt a broader and longer-term view of downsizing. Awareness of this need must be created among the senior level of management for two reasons: to ensure that 


\section{Table 1. The Organizations}

The ten organizations referred to in the article are described below. At the request of their respective organization, the names "Andersons," "Whitefields," "Midville," and "Northville" have been substituted to conceal their identity.

- Between 1975 and 1980, Imperial Chemical Industries (ICI), the British chemical manufacturer, closed Mountside works. The factory, situated in the northwest of England, employed more than 1,000 people.

- $\mathrm{ICl}$ closed another plant at Brookside in Scotland during the mid-seventies. In this case, local union officials put up considerable resistance, involving the press and political leaders in an effort to prevent the closure. They eventually accepted the decision, but only after national union leaders and the headquarters level of the company had been drawn into the negotiations, despite the fact that there was no enforced redundancy and all employees were given the option of working in another plant on the site.

- "Andersons" is an engineering multinational. In 1978, it announced the loss of 1,000 jobs in a Scottish factory. Attempts to bring in a new product to save the remaining 500 jobs failed, and the factory was closed in 1980. The company helped employees to set up a small engineering factory on the site of the old one to save 200 jobs.

- In June 1983, CIL, a divisionalized Canadian manufacturer and distributor of chemical and allied products, announced the partial closure of an explosives factory in an isolated community in Northern Ontario. There were 176 people involved, of whom 53 continued to work in the ongoing part of the operation. This, however, was closed in 1985.

- "Whitefields," a manufacturing multinational offered, in 1983, an early retirement option to all employees with 25 years service in its Canadian operations. Of more than 1,200 eligible employees, 432 accepted.

- Air Canada, the stateowned airline, offered a voluntary severance program to all of its managerial staff in August 1982. Nearly $18 \%$, more than 600 people, took advantage of the program.

- Atomic Energy of Canada Ltd. (AECL), the state-owned nuclear power agency, laid off over 500 people in its manufacturing operations in 1983.

- "Midville" and "Northville" AHAs both proposed hospital closures in the midseventies in response to funding cuts. At Midville, the proposed closure was implemented. At Northville, however, unions, employees and patient groups united in their opposition to the closure and the recommendation was overruled, forcing management to retain the hospital.

- Ville Marie is a social service agency in Montreal. In 1981, an $11 \%$ funding cut was announced by the provincial government of Quebec.

Nearly 200 interviews were carried out with managers, union officials, employees, and representatives of other interest groups in each organization. Documentationin the form of managerial and union reports, correspondence and memoranda, and newspaper articles - was also analyzed. 
the necessary cuts are made in a timely and logical manner, avoiding a crisis and allowing for a more humane approach to be put into place; and to secure a commitment among decision makers to a more enlightened approach and the investment which that entails.

A lack of awareness of the need for downsizing will result in counterproductive decisions which worsen an already difficult situation. At Atomic Energy of Canada Ltd. (AECL), where more than 500 individuals were laid off in 1983, previously full order-books in the late seventies and early eighties had obscured management's perceptions. Senior management was unwilling to face up to the prospect of layoffs even though the numbers showed that something was "definitely wrong." As a result, AECL was hiring new graduates up until 1981 (to arrive in 1982). Before the end of 1981 , however, the corporation had been forced to do an about-turn with a hiring freeze, followed by an announcement of layoffs in November 1982. This not only compromised managers' credibility, it left them with the difficulties of laying off additional staff and dealing with a disaffected group of people who had turned down other jobs to work for AECL. As a result, future graduates will look a little more critically at AECL's hiring promises.

Human resource managers at Air Canada, which has undergone a series of cost-cutting measures in recent years, took steps to persuade senior executives of the need for action. The experience of the American airline industry with recession and deregulation was "powerful ammunition" in this respect. It enabled them to convince senior management that cost cutting should begin as soon as possible while there was time to plan a more humane program than had been the case in most of the American companies.

Difficulties in predicting the future with any degree of certainty can be overcome. Managers at Ville Marie, a Montreal social service agency, knew the government planned to cut their budget in 1981, but not by how much. They responded by planning three scenarios representing cuts of $8 \%, 10 \%$, and $12 \%$. The knowledge accumulated in the process put them in a good position to effect the $11 \%$ cut they ultimately received.

Senior managers will provide the funds necessary to protect and support employees only if they consider it worthwhile. As a result, there is a need to impress upon them the hidden costs of retrenchment. The explosives division at CIL (the Canadian chemical manufacturer) effected the partial closure of a factory in a small town in Ontario. Divisional and human resource managers presented the executive committee with nine reasons why they should handle the closure carefully, ranging from the possibility of sabotage and other potential union problems to the difficulties of finding alternative employment in such an isolated area. The result was that a retrenchment program was approved, as were the funds (nearly $\$ 1$ million for 123 employees) required to carry it out. 


\section{The Task: Managing the Alternatives}

"We were prepared to seriously look at [alternative ways of reducing costs] if there was an emotion out there that wanted it." - a manager

The aim of creating awareness is to buy time and commitment, both of which allow a more flexible approach to downsizing, including the opportunity to consider some of the alternative methods of reducing costs. If action is taken early enough, attrition can be used to reduce personnel. Worksharing, early retirement, and voluntary severance as well as leaves of absence, pay freezes, and redeployments to other locations are other options for cost cutting. Since these methods involve an additional cost to the employer or take longer to have an effect, employers need to be well prepared to be able to make use of them.

Of particular interest to managers wishing to reduce the effect of retrenchment on employees is the question of whether severance can be conducted on a purely voluntary basis. Air Canada, ICI, and Whitefields (a manufacturing multinational which offered an early retirement option to all its Canadian operations staff with 25 -years service) all used voluntary programs.

Voluntary severance has been criticized as an expensive method of cutback: employees have to be paid to leave. However, even at AECLwhere more than 500 had already been laid off at the height of the recession, and the incentive offer "was not a rich package" -80 people took advantage of it.

The concern that the best people leave is not borne out in practice, since people have loyalties which bind them to the organization "regardless of the job market." Managers felt it was often the marginal performers who left; perhaps because they were disillusioned with their jobs and voluntary severance provided an opportunity to leave, or perhaps because they feared a less honorable discharge later. Even when experience is lost, the opening up of promotion opportunities more than compensates.

\footnotetext{
"A lot of people say nobody's indispensable and it seems to be true because [although] I was afraid when I saw the number of people leaving and the quality of those people, it turned out we could do without them ... [and it] certainly hasn't crippled us because what it's done has provided opportunities for people who were waiting. So we haven't really suffered even though we've lost a lot of experience."-a manager
}

The company can always protect itself by stating formal conditions. Air Canada reserved the right of refusal in cases where scarce skills would be lost to the competition. Informal persuasion can be used to ease out some of the more marginal performers. However, voluntary programs must be seen to be voluntary to be effective. Managers must not be perceived as "leaning" on people. Nor must there be too many denials: even at Air Canada there was pressure from the CEO down to let everyone go unless there were some "really dire circumstances." A "voluntary 
program" also means accepting the numbers who apply, be they above or below expectations. Managers at Whitefields were willing to cut expenses or carry the extra overhead rather than fire anyone, in the event that an insufficient number of people volunteered.

Voluntary severance provides both the company and the employee with benefits. Employees are given a choice and there is no stigma attached to their dismissal. The company gains credibility by being seen to accommodate employee needs, which translates into commitment and productivity from continuing employees.

\section{The Task: Managing Involvement}

"[The joint committee] worked well because what it did was keep the company and the union working together, solving the problems. By making them participants I think it was much more successful."-a manager

Employees will be worried about the impact the cutbacks will have. Involving representatives in at least part of the decision-making process helps to reduce feelings of powerlessness and provides a forum in which employee interests can be protected.

Companies that restricted involvement have met with criticism. Andersons, a multinational which had set up a feasibility study to investigate the closure of a Scottish engineering factory with 1500 employees, refused to allow union participation or to release the figures on which the recommendation for closure was based. The result was a great deal of suspicion concerning the company's motives and an unwillingness to believe that the closure was necessary.

"Andersons has a traditional position-they make a decision and the union agrees

... I think they made a mistake. If they'd come to the same decision with union involvement it would have been easier to accept."- a union official

Beliefs that effective involvement cannot be created around the issue of cutbacks are unfounded. Mechanisms were established to facilitate employee involvement in most of the organizations. At Mountside, a special committee was set up with union and management representation to secure the cooperation of the senior stewards. It brought together the two sides as a problem-solving group, avoiding the need to resort to the formal negotiating procedure. It made recommendations concerning employee needs to the works manager, who was then able to make decisions fully aware of the likely consequences. He sometimes made concessions, for example, allowing people to leave before their termination date (with full severance pay) if they found another job. This helped win the goodwill of the stewards. They felt they were an active part of the process, able to safeguard their own interests rather than having to watch helplessly from the sidelines. The committee acted as a safety valve, achieving a "remark- 
able degree of trust on both sides" and preventing any industrial unrest.

At CIL, placement committees were established with managers and union representatives to consider the issues of retraining, counselling, and outplacement. Federal legislation dictated the establishment of a Joint Planning Committee at AECL with union/employee and management membership and an independent chair. For each of the four employee groups, the corporation also set up Joint Manpower Adjustment Committees (JMACs), with a similar format, to handle the grievances and outplacement needs of the particular group.

\section{The Task: Managing Fair Play}

"[It's important that the] employee group perceives there's been a lot of fairness, a lot of trust and the selection process is done fairly objectively; because if it isn't, the more you upset people."-a manager

Employees were reassured by a sense of fairness in how the process was handled, particularly when managers were forced to undertake enforced dismissals involving some sort of selection process. A perception of fairness prevents the initiation of grievances and provides some security to continuing employees.

Three common selection criteria are seniority, required skills, and performance. Seniority has the advantage of being a criterion that workers "relate to," helping them to view dismissals "in a rational fashion" and accept the choices that are made. Some critics argue that it robs the organization of its young blood. However, the problem with the other two criteria is that they are more subjective and decisions may be contested. Unions at AECL disagreed with the selection criteria that were used to protect critical skills, initiating over 100 grievances, some of which they won in arbitration.

On another issue, AECL's sense of fair play was commended: its willingness to handle unionized and nonunionized groups in the same way. Of the four employee groups at the corporation, only two were represented by unions. However, JMACs were set up on the same basis for all these groups, and management established grievance procedures for the nonunionized employees who were not protected by collective agreements.

Discrimination between management and nonmanagement employees creates a sense of injustice. Air Canada ran into this problem: voluntary severance was offered only to managers on the basis that their jobs were being terminated permanently. Other employees were laid off on a temporary basis according to union contracts and did not qualify for the same severance pay. Despite the difference in the nature of the layoffs, union representatives felt that their members were being discriminated against and management had a difficult time explaining the position to them. 


\section{The Task: Managing Support}

"It's marvellous how it's been done. Every help one could imagine was there."- $a$ manual worker

A variety of support mechanisms can prove invaluable in helping employees deal with job loss, which enhances managerial credibility in the eyes of both departing and continuing employees and provides a firm foundation for future employee relations. Of particular importance here are attempts to reduce the insecurity of employees, such as with severance pay and help in finding new jobs.

All the firms provided some sort of severance pay. Both Andersons and ICI exceeded the state minimum. ${ }^{8}$ Air Canada offered one month per year of service (up to 18 months). Whitefields offered two years' salary over the following four years. CIL instituted a minimum of $\$ 4,000$ and paid between one and two weeks' pay per year of service. AECL offered one week's pay per year of service with a variety of supplements providing up to an additional 55 days' pay for some employees.

Outplacement also helps employees. ICI advertized on behalf of its employees, appointed a redeployment manager, set up a "job shop" in which vacancies were posted, provided training in interview skills, and allowed paid time off to attend interviews. CIL provided job search seminars, moving expenses, job search expenses, paid time off, retirement counselling, and financial planning. AECL undertook "ad tracking" on behalf of employees, posted vacancies, advertized, provided seminars on job search techniques, offered secretarial support, staffed an outplacement center, and organized a job fair in which potential employers were invited on site. This type of aid has a positive impact at a relatively low cost.

"There's no denying that providing that sort of [outplacement] aid helps the acceptance of the pain of workforce reduction. . . . It really doesn't cost you that much. It costs a lot in time and effort in the organizing, but it doesn't cost you in terms of dollars in cash outlay, and in some respects it's more appreciated."-a manager

Managers at Andersons took a somewhat different approach. First, they tried to save some jobs by transferring a substitute product to the Scottish factory. When that failed, they hired a consultant to conduct an international search for a buyer for the factory and equipment. When this proved unsuccessful, a local search, instigated by the company and its employees, uncovered a demand for the engineering skills of the workforce. As a result, a small subcontracting engineering firm was set up, with the company's help, employing around 200 of the original employees.

\section{The Task: Managing Disclosure}

"The worst thing is the insecurity of not knowing."-an employee

Empirical studies agree that it is in the employees' interests if managers disclose as much information as they can, as soon as they can, as often as they can. Advance notice improve maralo and enhances the chances 
of finding another job. The absence of information, on the other hand, leads to rumor, which is usually more pessimistic than reality.

Some managers at Ville Marie withheld information, believing it would add to anxiety to say too much about impending cuts. Employees, however, found that the resulting rumors increased uncertainty and tension.

\footnotetext{
"It was mostly rumor. That's what we found so maddening-that there was nothing we could grasp. It was just rumor and it was very tense. Everyone was concerned that they might be cut and they didn't know whether it was going to be [on] seniority or not." - an employee
}

CIL sent specially trained counsellors to the closing plant on the day of the announcement "to get as much information to all the employees as quickly as possible." Even though they were not legally required to do so, AECL managers informed individuals of their future at the same time as the announcement of group dismissals (sixteen weeks in advance) to avoid having the entire corporation worry and thus having a detrimental effect on production.

Advance notice does not necessarily result in conflict, sabotage, or declining productivity, as is sometimes charged. The percentage of hours lost due to industrial action fell at Andersons from 18\% in 1977 to less than $1 \%$ in the first nine months of 1979 , after the announcement of redundancies. Absenteeism fell during the rundown process at Mountside, as did the number of customer complaints, while the output per man-weeks remained stable. Productivity actually rose at CIL.

It is not enough simply to inform employees at the beginning of the exercise; information should be updated as the retrenchment program progresses. A weekly bulletin at Mountside was issued both in a newssheet and via the internal telephone. It ran for more than two years and was revised weekly to ensure that employees were aware of what was happening.

Information should be realistic-raising false hopes can backfire. At another closure in ICI, three statements were made shortly before the closure was announced, indicating that there was no threat to jobs. The actual announcement took employees by surprise and they started to question the company's motives, blaming the closure on ineffective planning and accusing it of hiding the real situation from them.

\section{The Task: Managing Understanding}

"We spent so much time and effort in trying to get understanding of why it happened and how we were going to close it [the factory], and what help we were going to give, that acceptance became rather inevitable." - a manager

From the effective disclosure of information should come an understanding of why retrenchment is occurring, which is important if union officials and employees are to accept the cuts. Opposition arose at Northville because medical reasons for the cuts were disputed by medical staff, while the 
financial rationale was considered an unacceptable basis on which to cut health services.

Air Canada took a number of steps to create an understanding of the corporation's position throughout the organization. An audio-visual program was created called "The Air Canada Challenge," which included a film, articles in the company magazine, and meetings between managers and employees. It was used to explain what was happening in the industry in terms of costs, declining markets, and deregulation. Individuals were informed of the steps being taken to deal with these problems - the marketing efforts to attract new business, the measures to save gasoline, the steps to increase efficiency. Finally, it impressed upon employees the need for sacrifices, cost cutting, and increased productivity.

\section{The Task: Managing Blame}

"There has to be a very well argued case for closure-people need convincing. They are going to have to be satisfied that the reasons for closure are credible." $-a$ manager

One issue that will arise from trying to create an understanding of the reasons behind the cutbacks is the question of who is responsible. Managers have to choose between accepting responsibility for the current situation and directing the blame elsewhere. The latter can be a very risky strategy: if employees find out the reasons for cutbacks are not valid, they will start to question the entire retrenchment exercise, and management will find itself the subject of a great deal of suspicion.

Andersons's attempt to blame the closure on falling world demand was contested by the unions who felt it was a "cosmetic exercise" designed to placate financial institutions worried about their investments. The closure was interpreted as a political move rather than a financial necessity and the unions felt that they could pressure the company into changing its decision.

Managers can sometimes take advantage of an external scapegoat. Although the Mountside closure was part of a rationalization plan, managers tended to blame it on the old age of the plant and the proximity of the potentially dangerous chemical plant to a hospital and residential area. These reasons were visible, comprehensible, and had the added advantage of absolving management from all blame. In this case, the "scapegoating" worked, as did a similar situation at Midville AHA where a proposed hospital closure was blamed on government spending cuts, even though:

"I know darn well that had we had the money we still would have closed it. They [the unions] don't realize that. We were using the financial argument but what we were really after was rationalization."- a manager

If a clearly visible scapegoat exists, one that does not implicate management and that is easy to understand, managers may choose to use it. If, 
however, the explanation is complicated or contentious, this strategy may well backfire.

\section{Conclusion: The Task is Managing Survival}

"It's like most dollars ahead of people decisions. They are short term in their good effect, and long term in their bad effect; if indeed there is any good effect." - $a$ manager

Retrenchment should not be viewed as an unpleasant but short-lived affair, to be put to one side and forgotten as soon as possible. It is an investment in the future, the basis on which success depends. Layoffs are the price that a company or institution is prepared to pay. That price will only produce benefits if retrenchment does not hamper the return to viability. For retrenchment to play its part in the performance of the organization, it should be part of an integrated strategy to restore competitiveness, with a focus on all the necessary ingredients for success.

While this article finishes with the larger picture, managers ideally should start with it. Managers and employees need to know where the organization is going and how it intends to get there-and whether more cuts are part of that picture. Only in this way can managers assess the hidden costs and design a program accordingly. Moreover, it is only by knowing that retrenchment lies ahead that managers can take timely action, use alternative measures, prevent hiring mistakes, and demonstrate to employees that their sacrifices will indeed produce a more viable organization. The earlier the recognition that retrenchment is part of a survival strategy, the more likely it is to be viewed as an investment rather than a crisis. With this type of forward thinking and proactive planning, managers should be thinking of how to manage survival, rather than how to manage retrenchment. They can then carry out the necessary tasks to successfully implement the program, which include:

- extending awareness of the situation to all senior management;

- considering alternatives and less disruptive ways of downsizing;

- involving employee representatives;

- maintaining a sense of fair play;

- providing the necessary support;

- disclosing information to employees;

- ensuring that they understand the need for cutbacks; and

- dealing with the issue of blame.

This article has used the experiences of some Canadian and British organizations to illustrate some of the reasons why managers should view retrenchment decisions like any other kind of investment. This is not to say that retrenchment is easy, or that those employees affected by it will not suffer from the loss of their jobs and from uncertainty, financial insecurity, and stress. Under any circumstances, retrenchment means less for 
some people - that makes it difficult to manage, and it transforms a business problem into an acute personal problem for many people. What the experiences of these organizations does show, however, is that there are more and less effective ways of managing retrenchment and, for the most part, the more commercially effective methods also provide benefits for the employees. Retrenchment will never be painless, but it most certainly can be made less painful.

\section{References}

1. The NHS structure described in the article refers to the situation following the 1974 Reorganization.

2. See, for example, J.P. Gordus, P. Jarley, and L.A. Ferman, Plant Closings and Economic Dislocation (Kalamazoo, MI: W.E. Upjohn Institute for Employment Research, 1981); L. Greenhalgh, "Managing the Job Insecurity Crisis," Human Resources Management, 22/4 (1983):431-444; S. Luce, Retrenchment and Beyond (Ottawa: The Conference Board, 1983); B. Portis and M. Suys, A Study of the Closing of the Kelvinator Plant in London, Ontario (London, Ontario: University of Western Ontario, 1970); R.I. Sutton, "Managing Organizational Death," Human Resources Management, 22/4 (1983):390412.

3. A.B. Carroll, "When Business Closes Down: Social Responsibilities and Management Actions," California Management Review, 26/2 (Winter 1984):129; Also, see R.B. McKenzie, Plant Closings: Public or Private Choices? (Washington, D.C.: The Cato Institute, 1982).

4. Carroll, op. cit., pp. 125-140; B. Bluestone and B. Harrison, The Deindustrialization of America (New York, NY: Basic Books, 1982); N.R. Folbre, J.L. Leighton, and M.R. Roderick, "Plant Closings and their Regulation in Maine, 1971-82," Industrial \& Labor Relations Review, 37/2 (1984):185-196.

5. The Conference Board, Company Programs to Ease the Impact of Shutdowns (New York, NY: The Conference Board, 1986).

6. T.F. Buss and F.S. Redburn, Shutdown at Youngstown: Public Policy and Unemployment (New York, NY: State University of New York Press, 1983); B. Harrison, "Plant Closures: Efforts to Cushion the Blow," Monthly Labor Review, 87/6 (1984):41-43; T.A. Kochan, R.B. McKersie, and P. Cappelli, "Strategic Choice and Industrial Relations Theory," Industrial Relations, 23/1 (1984):16-39.

7. Carroll, op. cit., pp. 125-140; William L. Batt, "Canada's Good Example with Displaced Workers," Harvard Business Review, 6/22 (July/August 1983).

8. In Britain, redundancy compensation is mandatory. Minimum requirements are $1 / 2$ week's pay per year of service while age 18-21; one week's pay per year of service while age $22-41 ; 1 \frac{1}{2}$ week's pay while age $42-65$. This is for employees with more than 2 years of service up to a maximum of 20 years of service. The state reimburses $41 \%$ of this amount. 
Copyright of California Management Review is the property of California Management Review and its content may not be copied or emailed to multiple sites or posted to a listserv without the copyright holder's express written permission. However, users may print, download, or email articles for individual use. 